\title{
Study and Design of Printed Rectangular Microstrip Antenna Arrays at an Operating Frequency of 27.5 GHz for 5G Applications
}

\author{
S. Didi1,*, I. Halkhams¹, M. Fattah², Y. Balboul11, S. Mazer¹, M. El Bekkali ${ }^{1}$ \\ ${ }^{1}$ IASSE Laboratory, Sidi Mohamed Ben Abdellah University, Fez, Morocco \\ ${ }^{2}$ IMAGE Laboratory, Moulay Ismail University, Meknes, Morocco
}

(Received 15 June 2021; revised manuscript received 16 December 2021; published online 20 December 2021)

In this paper, the authors studied and designed a simple patch antenna with a rectangular shape and exploited it to construct an array formed by two antennas in parallel and another one formed by four antennas in parallel in the $5 \mathrm{G}$ millimeter band with an operating frequency of $27.5 \mathrm{GHz}$. This study aims to obtain better antenna performances like gain, directivity, $S_{11}$, bandwidth, and efficiency. In this paper, we use a polyamide-type substrate with relative permittivity $\varepsilon_{r}$ of constant value equal to 4.3 , thickness $h_{s}$ of constant value equal to $0.15 \mathrm{~mm}$, width $W_{g}=3.77 \mathrm{~mm}$ and length $L_{g}=4.55 \mathrm{~mm}$, which represents a suitable material for antenna designs proposed in this paper. Furthermore, in this paper, the total size of this single printed antenna is equal to $2.578 \times 3.35 \times 0.15 \mathrm{~mm}^{3}$. The single patch antenna resonates at $27.0787 \mathrm{GHz}$ with a return loss $\left(S_{11}\right)$ measurement value equal to $-28.1548 \mathrm{~dB}$, a bandwidth value equal to $1.03 \mathrm{GHz}$, a VSWR of 1.081 , a gain value equal to $6.3 \mathrm{~dB}$, a directivity value equal to $6.7 \mathrm{~dB}$, and radiation efficiency of $92.64 \%$. The proposed $1 \times 1$ antenna array operates at $27.42 \mathrm{GHz}$ and improves the performance achieved with a previous single antenna as follows, including $S_{11}$ (down to $-30 \mathrm{~dB}$ ), gain (7.3 dB), and directivity $(7.8 \mathrm{~dB})$. Similarly, the proposed $2 \times 2$ antenna array successfully improves $S_{11}$ down to $-31.7 \mathrm{~dB}$, gain up to $10.6 \mathrm{~dB}$, bandwidth up to $1.07 \mathrm{GHz}$, and directivity up to $11.2 \mathrm{~dB}$ at a resonant frequency of $27.078 \mathrm{GHz}$. The antenna designs presented in this paper are performed using the highfrequency structure simulation (HFSS) tool. In addition, antennas proposed in this paper are adapted to the $27.5 \mathrm{GHz}$ frequency range as well as applied to the $5 \mathrm{G}$ mobile communication system.

Keywords: 27.5 GHz, Millimeter wave, Printed antenna, Printed antenna array, 5G, HFSS.

DOI: 10.21272/jnep.13(6).06035

PACS numbers: 84.40.Ba, 84.40. $-\mathrm{x}$

\section{INTRODUCTION}

Millimeter-wave frequencies provide high capacity and thus allow a considerable amount of data to be transferred across a specific transmission path to achieve multi-gigabit per second transmission rates, associated with increased reaction times $[1,2]$. These characteristics make it possible to envisage attractive prospects for the provision of fast wired Internet connections and data and video trains, not to mention the possibilities of replacing existing cables. On the other hand, appropriate and reliable construction procedures and techniques are needed to study and then design antennas with the required performance for the fifth generation ("5G"), as well as predictive time and frequency domain simulations that can efficiently handle printed antennas [3,4]. Fifth generation ("5G") millimeter-wave frequency bands, including those in the 24.25-27.5 GHz and 57-64 GHz ranges, have received a lot of public interest due to their broadband characteristics that can support higher capacity and data rates for mobile communication systems [5-9]. Nevertheless, these frequency bands are subject to several obstacles, including (a) considerable propagation loss, (b) fading by multiple transmission paths, and (c) interference from various types of channels. To recover these losses, very high-performance antennas must be used. Multibeam antennas or arrays are necessary to avoid jamming and interference caused by multipath broadcasting [6-10].

An antenna is a device for radiating or receiving ra- dio waves in space. There are antennas for transmitting and receiving electromagnetic signals and radio signals. The patch or printed antenna is a planar-type device, and its radiating element usually consists of a conductive surface of various geometries such as square, rectangular, triangular, etc., separated by dielectric insulating support from the conductive reflection plane [3, 7].

An antenna array is a set of separate synchronously fed radio antennas. It means that the phase shift of the current between two pairs of antennas is constant. The antenna array may contain several antennas, fed by the field generated by other elements instead of the source directly (parasitic elements) (this is the case of Yagi-Uda antennas). The electromagnetic field created by an antenna array is the sum of the vector fields generated by each element. The proper choice of the distances between the various antennas and their current phase allows modifying the directivity of the array by creating constructive interference in some directions and destructive interference in other orientations [8].

In this paper, we perform a study and design necessary to construct a single patch antenna and use it to create an antenna array consisting of two antenna elements in parallel and an array formed by four single patch antenna elements arranged through parallel. The general plan of this work is structured as follows. The first step is devoted to the necessary introduction, the second step concerns the procedure used to study and design the proposed simple antenna, the third step is going to be devoted to the study of two-piece antenna

\footnotetext{
*salaheddine.didi@usmba.ac.ma
} 
arrays, the fourth step carries a study of four-piece antenna arrays. We will analyze and discuss in more detail all the simulation results obtained in this paper, as well as their comparison with existing ones. We employ high-frequency structure simulation (HFSS) software for these designs. Finally, in the fifth part, we end this paper with conclusions.

\section{SINGLE ANTENNA}

\subsection{Single Rectangular Antenna Design Method}

In this paragraph, we explain the design procedure for microstrip patch antennas, including the process of calculating the parameters of the patch antenna, meaning its length $(L)$ and its width $(W)$, as well as the dimensions of the ground surface, precisely its length $\left(L_{g}\right)$ and width $\left(W_{g}\right)$, and the electrical cables needed to feed them. We also explain the procedure to print the radiated element meaning the rectangular part of size $(L$, $W$ ) or the patch on the substrate. This substrate plays a double role in microstrip technology. It is both a dielectric material, where the circuits are etched, and a mechanical part because it supports the structure. To facilitate the study and design of printed antennas with better performance, we propose a simple rectangular printed antenna design with an operating frequency of $27.5 \mathrm{GHz}$ intended for $5 \mathrm{G}$ applications, as shown in Fig. 1. The substrate chosen for this design is a polyamide material having a relative permittivity of constant value $\varepsilon_{r}$ equal to 4.3 and a height $h_{s}$ equal to $0.15 \mathrm{~mm}$. Polyamide is a frequently used material for coating metal substrates and is supplied by a microstrip line. The quarter-wave transformer also refers to the microstrip cable used to ensure a proper match between the impedances. The reference formulas of $[3,11]$ are used for the calculation of the length and width of the microstrip feeder cable $\left(L_{a}, W_{a}\right)$, as well as the proposed antennas $(L, W)$.

Using formula (1), we obtain the proposed antenna width $W$ :

$$
W=0.5 \frac{c}{f r}\left(\frac{2}{\varepsilon_{r}+1}\right)^{\frac{1}{2}}
$$

Using formula (2), we obtain the value of the length $L$ of the radiated element, in other words, the patch:

$$
\begin{gathered}
L=L_{\text {eff }}-2 \Delta L=\frac{c}{2 f r \sqrt{\varepsilon_{\text {eff }}}}-2 \Delta L, \\
\Delta L=0.412 \frac{\left(\varepsilon_{\text {eff }}+0.3\right)\left(\frac{W}{h s}+0.264\right)}{\left(\varepsilon_{\text {eff }}-0.258\right)\left(\frac{W}{h s}+0.8\right)}, \\
\varepsilon_{\text {eff }}=\frac{\varepsilon_{r}+1}{2}+\frac{\varepsilon_{r}+1}{2}\left(1+12 \frac{h s}{W}\right)^{\frac{-1}{2}} .
\end{gathered}
$$

The ground plane dimensions are the following: $W_{g}=W+6 h_{s}$ and $L_{g}=L+6 h_{s}$. Letter $W$ denotes the width of the radiated element (patch), as well as letter
$L$ corresponds to the length of the radiated element, $f_{r}$ represents the operating frequency $f_{r}=27.5 \mathrm{GHz}$, letter $c$ stands for the speed of light whose constant value is equal to $3 \cdot 10^{8} \mathrm{~m} / \mathrm{s}, \Delta L$ is the stretching distance, the coefficient $h_{s}$ stands for the thickness of the dielectric that means the thickness of the substrate, the factor $\varepsilon_{\text {eff }}$ corresponds to the effective permittivity of the dielectric that means the permittivity of the substrate, the factor $W_{g}$ stands for the width of the ground plane, the factor $L_{g}$ stand for the length of the ground plane.

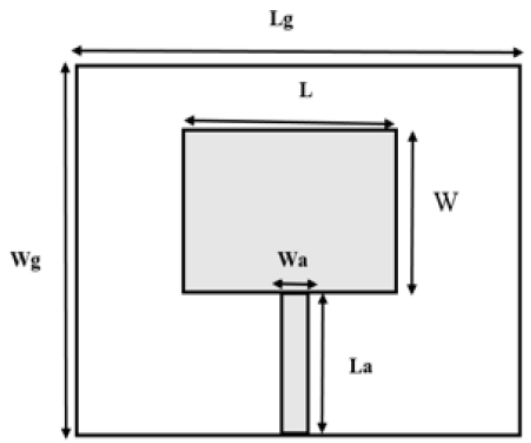

Fig. 1 - Structure envisaged for this printed antenna

Table 2 - Summarized values of the parameters obtained in the design of this patch antenna

\begin{tabular}{|c|c|}
\hline Parameter & Value $(\mathrm{mm})$ \\
\hline$L_{g}$ & 4.550 \\
\hline$W_{g}$ & 3.778 \\
\hline$h_{s}$ & 0.150 \\
\hline$W$ & 2.578 \\
\hline$L$ & 3.350 \\
\hline$L_{a}$ & 0.200 \\
\hline$W_{a}$ & 0.060 \\
\hline
\end{tabular}

\subsection{Simulation Results and Discussion}

Simulation of this antenna was performed in Ansys HFSS - a high-frequency electromagnetic field simulation tool. The choice of the position of the excitation source plays an essential role in the design of the antenna. Therefore, we first choose the excitation point to excite the optimized patch through a microstrip feed wire in different feed positions. In this section, the correct feed line position is the midpoint of the radiated element (patch). Thus, the results of the simulation of this antenna are as follows.

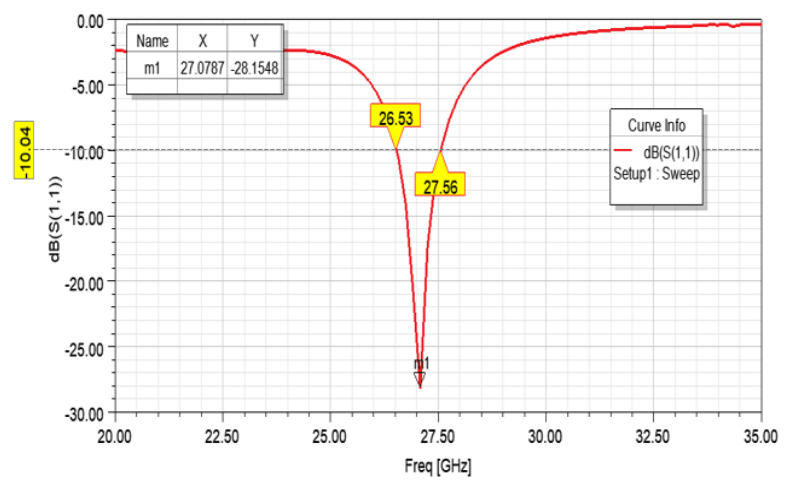

Fig. 2 - Parameter $S_{11}$ of the antenna studied in this work 
The return loss $S_{11}$ of an antenna is an essential parameter to evaluate the ratio of the reflected signal to the incident signal. This antenna resonates at $27.0787 \mathrm{GHz}$ with a reflection coefficient of $-28.1548 \mathrm{~dB}$, a bandwidth of $1.03 \mathrm{GHz}$, an VSWR of 1.081, as shown in Fig. 2.

The gain of an antenna in a preferred orientation is the ratio of the transmitted power density in that orientation to that obtained with a standard antenna, i.e., an isotropic antenna. The proposed antenna has a gain of $6.3 \mathrm{~dB}$, as shown in Fig. 3 .
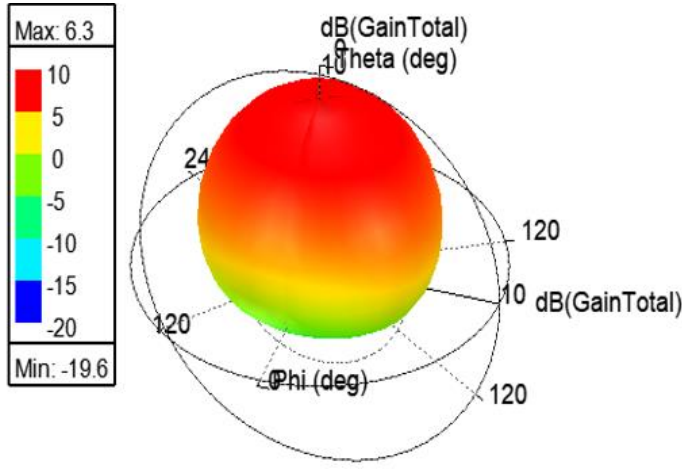

Fig. 3 - Schematic of the radiation pattern of this antenna in 3D

The directivity of an antenna in a given direction is the power density radiated by the antenna in that direction relative to its average over the entire space. This antenna has a directivity of $6.7 \mathrm{~dB}$, as shown in Fig. 4.
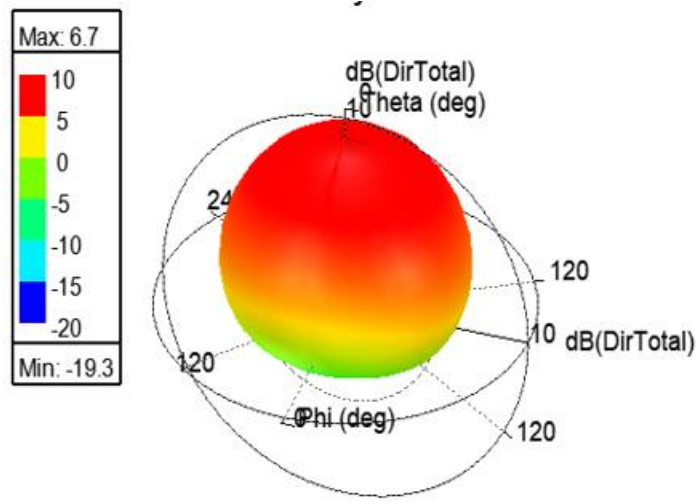

Fig. 4 - Graphic representation of the directivity of the proposed antenna

\section{$\mathbf{L}$}

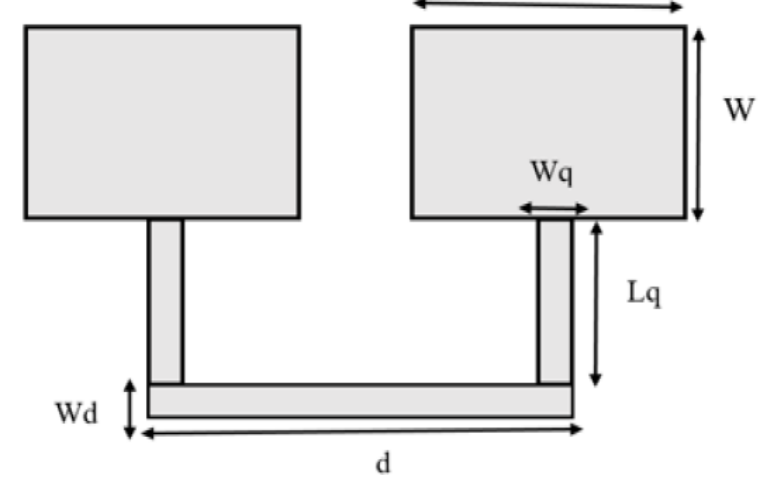

Fig. 5 - The proposed antenna array

\section{TWO-PATCH ANTENNA ARRAY}

The objective of this antenna array is to improve the performance of the above individual antenna, especially in terms of gain and directivity. Table 3 summarizes different design parameters and Fig. 5 shows the antenna array consisting of two patches.

This array of antennas resonates at $27.4157 \mathrm{GHz}$, with a return loss of $-30.0548 \mathrm{~dB}$, a bandwidth of $0.76 \mathrm{GHz}$, an VSWR of 1.0648 , a gain of $7.3 \mathrm{~dB}$, and a directivity of $7.8 \mathrm{~dB}$, as shown in Fig. 6 .

Table 3 - Antenna array parameters

\begin{tabular}{|c|c|}
\hline Parameter & Value (mm) \\
\hline Substrate length $L_{s}$ & 9.100 \\
\hline Substrate width $W_{s}$ & 3.778 \\
\hline Substrate height $h_{s}$ & 0.150 \\
\hline$W$ & 2.578 \\
\hline$L$ & 3.350 \\
\hline$W_{q}$ & 0.200 \\
\hline$L_{q}$ & 0.200 \\
\hline$W_{d}$ & 0.200 \\
\hline$d$ & - \\
\hline
\end{tabular}
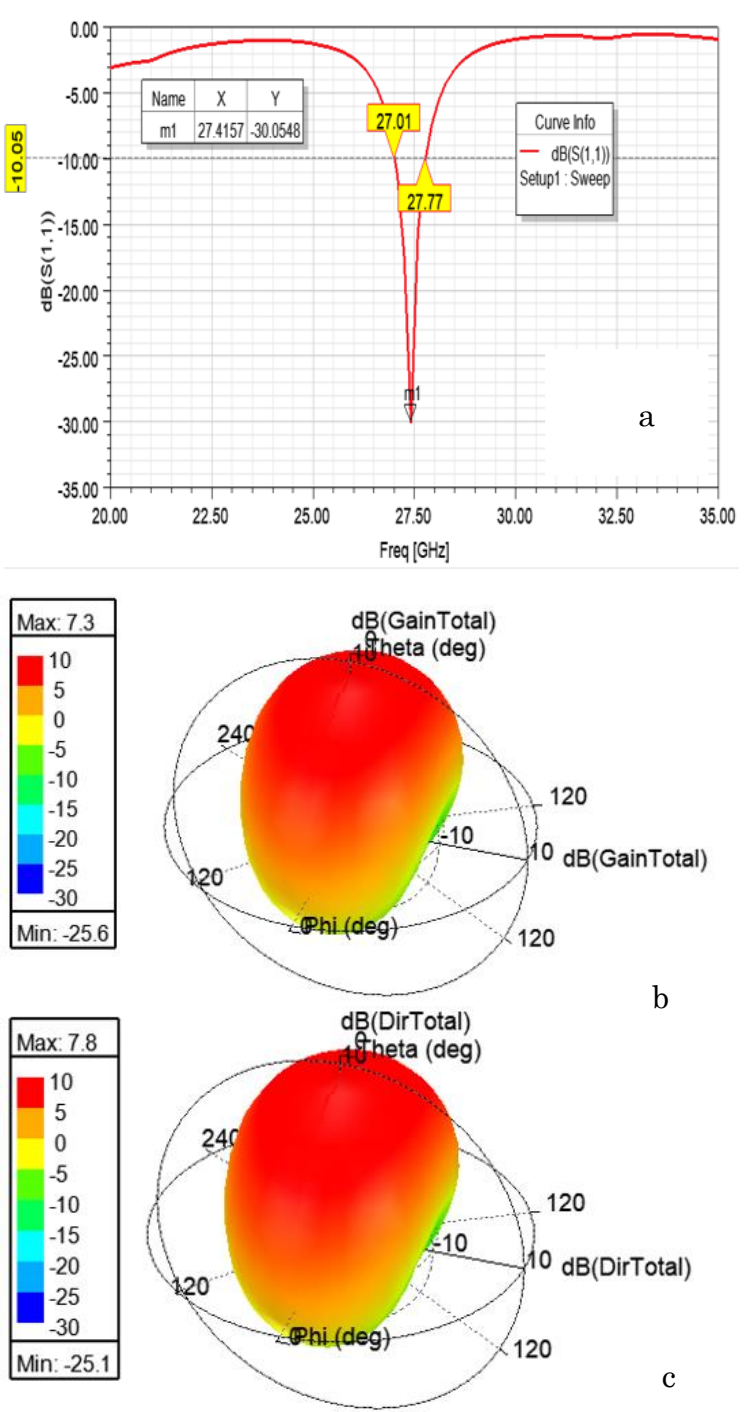

Fig. 6 - $S_{11}$ (a), gain (b) and directivity (c) 


\section{FOUR-PATCH ANTENNA ARRAY}

The objective of this antenna array is to improve the parameters related to the previous single patch antenna like gain, directivity, and bandwidth. This proposed array of antennas is etched in a substrate with relative permittivity $\varepsilon_{r}=4.3$.

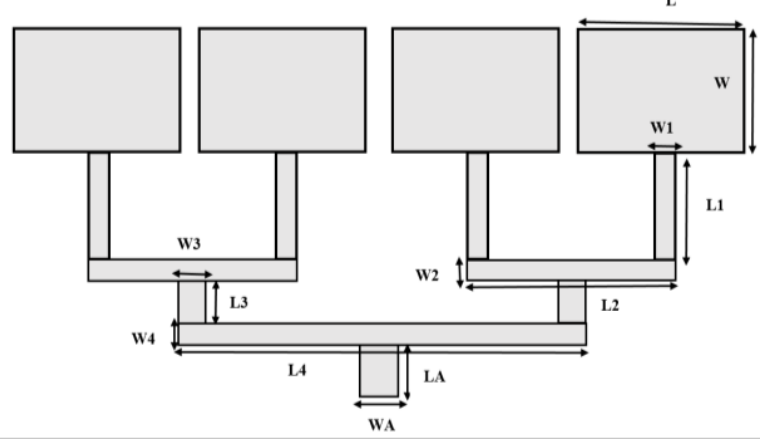

Fig. 7 - Proposed antenna array

Table 4 - Antenna array parameters

\begin{tabular}{|c|c|}
\hline Dimensions (width, length) & Measurements (mm) \\
\hline$L_{1}$ & 0.2 \\
\hline$W_{1}$ & 0.2 \\
\hline$L_{2}$ & 4.95 \\
\hline$W_{2}$ & 0.2 \\
\hline$L_{3}$ & 0.2 \\
\hline$W_{3}$ & 0.2 \\
\hline$L_{4}$ & 9.7 \\
\hline$W_{4}$ & 0.2 \\
\hline$W_{A}$ & 1.022 \\
\hline$L_{A}$ & 0.3 \\
\hline
\end{tabular}

Fig. 7 shows the four-patch antenna array, and Table 4 summarizes different design parameters. This antenna array resonates at $27.078 \mathrm{GHz}$ with a reflection coefficient of $-31.7 \mathrm{~dB}$, a bandwidth of $1.07 \mathrm{GHz}$, a VSWR of 1.054, a gain of $10.6 \mathrm{~dB}$, and directivity of $11.2 \mathrm{~dB}$, as shown in Fig. 8 .

The gain provided by the antenna [15] is higher than that of other antennas; however, it has two drawbacks: very low bandwidth and large size. On the other hand, the $S_{11}$ and bandwidth of this antenna [14] are better than those obtained for other antennas. The proposed antenna has a high radiation efficiency and small size compared to other antennas, but also larger bandwidth than other antennas $[13,15]$. The $S_{11}$ reflection coefficient of the twoelement array cited in [17] is much better than those of any other array. However, the proposed twoelement antenna array has the best performance compared to other arrays [16, 17], including gain, directivity, bandwidth, and radiation efficiency. Furthermore, the performance of our proposed fourelement antenna array is better than that of any other array [16, 17], especially in terms of gain, directivity, bandwidth, and radiation efficiency.
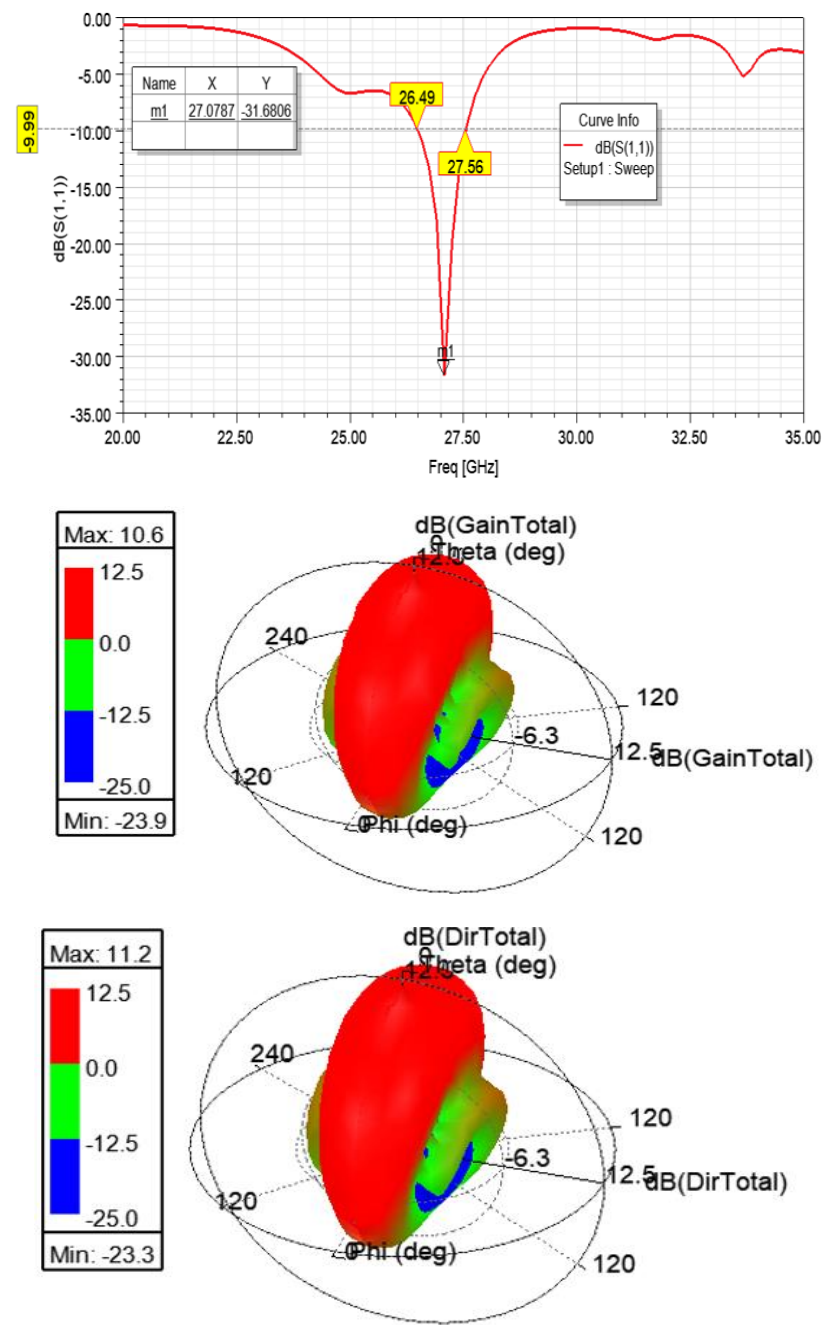

Fig. 8 - $S_{11}$ (a), gain (b) and directivity (c)

\section{CONCLUSIONS}

In this paper, the authors have studied and designed a single patch or printed antenna, a two-element antenna array, and a four-element antenna array in the context of $5 \mathrm{G}$ applications.

The simulation results obtained for the fourelement array antenna are summarized as follows: the reflection coefficient is $-31.7 \mathrm{~dB}$, the gain is $10.6 \mathrm{~dB}$, the bandwidth is $1.07 \mathrm{GHz}$, and the directivity is $11.2 \mathrm{~dB}$ with a resonant frequency of $27.078 \mathrm{GHz}$. These performances are much better than those obtained for a single patch antenna, two-element arrays and antennas listed in Table 5 and Table 6.

The antenna and antenna arrays presented in this paper have addressed the needs of millimeter-wave operation at a frequency of $27.5 \mathrm{GHz}$, and also simplify design and reduce manufacturing costs. These results obtained with the proposed antennas are very interesting for millimeter-wave applications, as well as for 5G technology systems. These antennas are also adequate for $5 \mathrm{G}$ wireless applications, thanks to their excellent characteristics and reduced costs of production. 


\section{REFERENCES}

1. D. Helena, A. Ramos, T. Varum, JN. Matos, J. Sensors 21 No 10, 3321 (2021).

2. L. Chettr, R. Bera, IEEE Internet Things J. 7 No 1, 16 (2020).

3. S. Didi, I. Halkhams, M. Fattah, Y. Balboul, S. Mazer, M. El Bekkali, International Conference on Digital Technologies and Applications (ICDTA), 1081 (Fez, Morocco: Springer and Cham: 2021).

4. A. Es-saqy, M. Abata, M. Mehdi, S. Mazer, M. Fattah, M. El Bekkali, C. Algan, IJECE 11 No 2, 1036 (2021).

5. A.L. Swindlehurst, E. Ayanoglu, P. Heydari, F. Capolino, IEEE Commun. Magaz. 52 No 9, 56 (2014).

6. H. Jiang, LM. Si, W. Hu, X. Lv, IEEE Photon. J. 11 No 1, 4600409 (2019).

7. O. Picon, Antennas Theory, design and application. French center for the exploitation of coupier law (Paris: 2009).

8. V. Midasala, P. Siddaiah, International Conference on Computational Modeling and Security (CMS), 401 (Elsevier B.V: 2016).
9. N. Vivek, S. Kumar B, K. Shambavi, IJEET 12 No 5, 148 (2021).

10. H. Niamat, A.A. Wahaj, A. Wael, I. Naqvi, A. Zaidi, T. Tu Le, AEU IJEC 132 No 153612, 1 (2021).

11. P. Merlin Teresa, G. Umamaheswari, IETE J. Res. 66 No 5 , 1 (2020).

12. Ms. Prachi, V. Gupta, S. Vijay, IJITEE 9 No 3, 3696 (2020).

13. O. Darboe, D. Bernard, O. Konditi, F. Manene, IJERT 12 No 6, 854 (2019).

14. N.T.K. Thu, C.T. Nghia, L. Anh Duc, N. Thi Quynh Hoa, IJS 49 No 2A, 57 (2020).

15. M. Darsono, A.R. Wijaya, International Conference on Innovation in Research (ICIR), 1 (Bali, Indonesia: 2018).

16. S. Johari, M. Abdul Jalil, I. Shaifol Ifrad, M. Nazry Mohammad, H. Norhafiza, JESR 2 No 4, 1 (2018).

17. Yusnita Rahayu, Muhammad Ibnu Hidayat, 2018 2nd International Conference on Telematics and Future Generation Networks (TAFGEN), 93 (Kuching, Malaysia: IEEE: 2018).

\title{
Вивчення та проектування масивів друкованих прямокутних мікросмугових антен на робочій частоті 27,5 ГГц для додатків $5 \mathrm{G}$
}

\author{
S. Didi ${ }^{1}$, I. Halkhams ${ }^{1}$, M. Fattah ${ }^{2}$, Y. Balboul ${ }^{1}$, S. Mazer ${ }^{1}$, M. El Bekkali ${ }^{1}$ \\ ${ }^{1}$ IASSE Laboratory, Sidi Mohamed Ben Abdellah University, Fez, Morocco \\ ${ }^{2}$ IMAGE Laboratory, Moulay Ismail University, Meknes, Morocco
}

\begin{abstract}
У роботі автори спроектували та дослідили просту патч-антену прямокутної форми та використали іiі для створення масиву, утвореного двома паралельними антенами, та ще одного масиву, утвореного чотирма паралельними антенами, в міліметровому діапазоні $5 \mathrm{G}$ з робочою частотою 27,5 ГГц. Дане дослідження спрямоване на отримання кращих характеристик антени, таких як підсилення, спрямованість, $S_{11}$, пропускна здатність та ефективність. У роботі ми використовуемо поліамідну підкладку з відносною діелектричною проникністю $\varepsilon_{r}=4,3$, товщиною $h_{s}=0,15$ мм, шириною $W_{g}=3,77$ мм і довжиною $L_{g}=4.55$ мм, яка є відповідним матеріалом для антенних конструкцій, запропонованих в роботі. Загальний розмір запропонованої друкованої антени становить $2,578 \times 3,35 \times 0,15$ мм $^{3}$. Одиночна патч-антена резонуе на частоті 27,0787 ГГц із значенням зворотних втрат $\left(S_{11}\right)$, рівним $-28,1548$ дБ, пропускною здатністю 1,03 ГГц, значенням параметру VSWR, рівним 1,081, підсиленням 6,3 дБ, спрямованістю 6,7 дБ, та ефективністю випромінювання $92,64 \%$. Запропонований масив антен $1 \times 1$ працюе на частоті 27,42 ГГц і покращуе характеристики розглянутої одиночної патч-антени наступним чином: $S_{11}$ зменшуеться до - $30 \mathrm{~dB}$, підсилення складае 7,3 дБ, а спрямованість дорівнюе 7,8 дБ. Аналогічно, запропонований масив антен $2 \times 2$ успішно покрашуе $S_{11}$ до $-31,7$ дБ, підсилення до 10,6 дБ, пропускну здатність до 1,07 ГГц і спрямованість до 11,2 дБ на резонансній частоті 27,078 ГГц. Конструкщії антен, представлені в роботі, виконані за допомогою інструменту моделювання високочастотних структур (HFSS). Крім того, антени, запропоновані в роботі, адаптовані до діапазону частот 27,5 ГГц, а також застосовуються до системи мобільного зв'язку 5G.
\end{abstract}

Ключові слова: 27,5 ГГц, Міліметрова хвиля, Друкована антена, Масив друкованих антен, 5G, HFSS. 